\title{
The Sensitivity of Computed Tomography in the Determination of Anterior Talofibular Ligament Tears
}

\author{
Anterior Talofibular Ligament Yırtıklarının \\ Belirlenmesinde Bilgisayarlı Tomografinin Duyarlılığı
}

\section{Özgün Araştrrma} Research Article

Alındı̆̆ı tarih: 08.05.2019

Kabul tarihi: 11.06 .2019

Online Yayın tarihi: 29.08.2019

Merve Gursoy

İmir Demokrasi Üniversitesi, Tıp Fakültesi,

Radyoloji Anabilim Dalı, Izmir - Türkiye

gursoymerve@yahoo.com ORCiD: 0000-0002-1225-2526

B. Dirim Mete 0000-0002-2380-4197 Izmir Demokrasi Üniversitesi, Tıp Fakültesi,

Radyoloji Anabilim Dalı, İzmir, Türkiye

Y. Çetinoğlu 0000-0002-7878-6117

O. Tosun 0000-0001-6755-2131

İmir Katip Çelebi Üniversitesi

Atatürk Eğitim ve Araștırma Hastanesi, Radyoloji Anabilim Dalı, Izmir, Türkiye

T. Bulut 0000-0002-7075-0873 Izmir Katip Çelebi Üniversitesi Atatürk Eğitim ve Araştırma Hastanesi, Ortopedi ve Travmatoloji Kliniği, Izmir, Türkiye

Cite as: Gursoy M, Dirim Mete B, Çetinoglu Y, Bulut T, Tosun O. The sensitivity of computed Bulut $\mathrm{T}$, Tosun $\mathrm{O}$. The sensitivity of computed
tomography in the determination of antetomography in the determination of ante-
rior talofibular ligament tears. Tepecik Egit. ve Araşt. Hast. Dergisi. 2019;29(2):140-7.

\section{Merve Gursoy $\odot$, Berna Dirim Mete $\odot$, Yusuf Çetinoğlu $\odot$, Tugrul Bulut $\odot$, Ozgur Tosun $\odot$}

\section{ABSTRACT}

Objective: The aim of this study was to determine the sensitivity, specificity, positive predictive value (PPV), negative predictive value (NPV) and accuracy of CT in the determination of anterior talofibular ligament (ATFL) tear by accepting the MRI results as the reference standard.

Methods: The study included a total of 62 ankle examinations of 60 patients with both ankle CT and MR images between 2010-2018. ATFL lesions were classified on both CT and MR images, as intact or torn (partial tear or complete tear). By accepting the MRI results as the reference standard the accuracy of CT in the determination of ATFL tears was estimated. The patients were also classified as Grade 0: normal on CT and MRI, Grade 1: thick on CT compatible with force, thick and with a high signal on MRI, Grade 2: partial tear, and Grade 3: complete tear. The probability of determining the same grade in both tests was calculated.

Results: CT was calculated to have $74.1 \%$ sensitivity, $100 \%$ specificity, $100 \%$ PPV, $96.4 \%$ NPV and $96.7 \%$ accuracy in the determination of ATFL tear. The probability of determining the same grade both on CT, and MRI was found to be $91.9 \%$.

Conclusion: CT has a high accuracy in the differentiation of intact ATFL from torn ATFL. Especially under emergency department conditions, the determination of whether the ATFL is intact or torn on $C T$, which is usually applied for the evaluation of bone pathologies, can refer the patient for MRI, and alter the form of treatment and the prognosis.

Keywords: Anterior talofibular ligament, computed tomography, magnetic resonance imaging, sensitivity

Öz

Amaç: Bu çalışmanın amacı, MRG sonuçlarını referans standart kabul ederek anterior talofibular ligament (ATFL) yırtıklarının belirlenmesinde BT'nin duyarlılık, özgüllük, pozitif prediktif değer (PPV), negatif prediktif değer (NPV) ve doğruluğunun belirlenmesidir.

Yöntem Calısmaya 2010-2018 yılları arasında ayak bileği BT ve MR görüntüleri olan 60 hastanın toplam 62 ayak bileği tetkiki dahil edildi. ATFL lezyonları hem BT hem de MR görüntülerinde sağlam veya yırtık (kısmi yırtık veya tam kat yırtık) olarak sınıflandıııldı. MRG sonuçları referans standart kabul edilerek ATFL yırtıklarının belirlenmesinde BT'nin doğruluğu hesaplandı. Hastalar aynı zamanda BT ve MRG'de evre 0: normal, evre 1: BT'de zorlama ile uyumlu kalın, MRG'de kalın ve yüksek sinyalli, evre 2: kısmi yırtık ve evre 3: tam kat yırtık olarak sınıflandırıldı. Her iki testte de aynı evreyi belirleme olasılığı hesaplandı.

Bulgular: ATFL yırtıklarını saptamada BT'nin \%74,1 duyarlıık, \%100 özgüllük, \%100 PPV, \%96,4 NPV ve \%96,7 doğruluk oranlarına sahip olduğu hesaplandı. BT'de sonucun MRG ile aynı evrede saptanma durumu \%91,9 olarak hesaplandı.

Sonuç: BT, intakt ATFL'nin yırtık ATFL'den ayrımında yüksek doğruluğa sahiptir. Özellikle acil servis kosulları altında, genellikle kemik patolojilerinin değerlendirilmesi için uygulanan BT'de ATFL'nin intakt veya yırtık olup olmadığının belirlenmesi ile hasta MRG'ye yönlendirilebilir, tedavi șekli ve prognoz değiștirilebilir.

Anahtar kelimeler: Anterior talofibular ligament, bilgisayarlı tomografi, manyetik rezonans görüntüleme, duyarlılık

(c) Telif hakkı T.C. Sağlık Bakanlığı İzmir Tepecik Eğit. ve Araşt. Hastanesi. Logos Tıp Yayıncılık tarafindan yayınlanmaktadır. Bu dergide yayınlanan bütün makaleler Creative Commons Atff-GayriTicari 4.0 Uluslararası Lisansı ile lisanslanmıştr.

(c) Copyright Association of Publication of the T.C. Ministry of Health izmir Tepecik Education and Research Hospital.

This journal published by Logos Medical Publishing.

Licenced by Creative Commons Attribution-NonCommercial 4.0 International (CC BY-NC 4.0) 


\section{INTRODUCTION}

The anterior talofibular ligament (ATFL) is the most important lateral stabilizer of the ankle and the most frequently damaged ligament in ankle injuries ${ }^{(1)}$. Although the majority of cases with ATFL damage are treated conservatively, surgery may be necessary for $10 \%-20 \%$ of patients because of persistent pain and chronic ankle instability ${ }^{(2)}$. Imaging plays a critical role in treatment planning and ATFL damage can be identified with a high degree of accuracy using magnetic resonance imaging (MRI) which has a higher soft tissue resolution ${ }^{(3)}$. However, the first imaging methods applied to patients presenting at the emergency department because of a sprained ankle are usually direct radiographs and computed tomography (CT). If ATFL damage, which may be missed, is seen on $\mathrm{CT}$ requested for bone pathologies, a change can be made in the treatment planning in the early period before the development of ankle instability or the patient can be referred for MRI examination in this respect. Thus, if a surgical intervention is to be performed, it may be possible to repair the ligament in the same session. To the best of our knowledge, there is no study in the literature that has evaluated the sensitivity of CT in the evaluation of ATFL damage. The aim of this study was to determine the sensitivity, specificity, positive predictive value (PPV), negative predictive value (NPV) and accuracy of CT in the determination of ATFL damage by accepting the MRI results as the reference standard.

\section{MATERIALS and METHODS}

This retrospective study was approved by the Institutional Review Board of our hospital. Due to the retrospective nature of the study, informed consent of patients and providers was not required.

\section{Patients}

The study included a total of 62 ankle examinations of 60 patients with both ankle CT and MR images, which had been taken for any reason between 2010 and 2018. Bilateral ankle CT and MR images were available for 2 patients. The time interval between the CT and MRI was shorter than 2 weeks.

Patients were excluded from the study if they had a history of ankle surgery, if the time between the CT and MRI was longer than 2 weeks, or if the CT and MRI scans were not of sufficient diagnostic quality.

\section{CT and MRI Review}

CT scans were obtained with a 64-slice CT device (Somatom Definition, Siemens Healthcare, Forchheim, Germany) using the parameters of 120 kV, $120 \mathrm{mAs}, 144 \mathrm{~mm}$ FOV and 512x512 matrix. Axial slices were obtained and sagittal and coronal reformatted images were made on these slices.

The MRI scans were obtained on a 1.5-Tesla Signa MR unit (GE Medical Systems, Milwaukee, WI, USA) with the extremity coil in a supine position. Sagittal, axial and coronal proton density fat-suppressed (TR/TE: 2840/42, matrix: 320x256, FOV: $16 \mathrm{~cm}$ ) images, axial fast-spin echo (FSE) T2-weighted fat-suppressed (TR/ TE: 3550/60, matrix: 320x256, FOV: $16 \mathrm{~cm}$ ) images and axial and coronal FSE T1-weighted (TR/TE: 500/20, matrix: 320x288, FOV: $16 \mathrm{~cm}$ ) images were obtained as standard sequences. The slice thickness was $3 \mathrm{~mm}$ and the interslice gap was $1 \mathrm{~mm}$.

The $C T$ and $M R$ images were evaluated in separate sessions by a radiologist with 15 years of experience in the field of musculoskeletal radiology. Axial slices were used in the evaluation of ATFL lesions. ATFL lesions were classified on both $\mathrm{CT}$ and $\mathrm{MR}$ images as intact or torn (partial tear or complete tear). On CT, ligament contours that were sharp with preserved continuity were accepted as intact, and those with contour irregularity or loss of fiber continuity were accepted as tears. A partial tear was accepted as the presence of residual fibers and a complete tear as the complete loss of ligament continuity. On MRI, regular contours of the ligament and the appearance 
of a low signal were accepted as normal and an intrasubstance high signal without contour irregularity was accepted as forced. Loss of continuity of some fibers together with residual intact fibers and intrasubstance high signal were accepted as a partial tear, and complete loss of ligament continuity as a complete tear.

CT results were compared with MRI results which was accepted as as the reference standard.. The sensitivity, specificity, PPV, NPV and accuracy rates of CT in the determination of ATFL tears were calculated. The patients were also classified as Grade 0: normal on $\mathrm{CT}$ and $\mathrm{MRI}, \mathrm{Grade} 1$ : thick on CT compatible with forced, thick and with a high signal on MRI, Grade 2: partial tear, and Grade 3: complete tear. The proba-

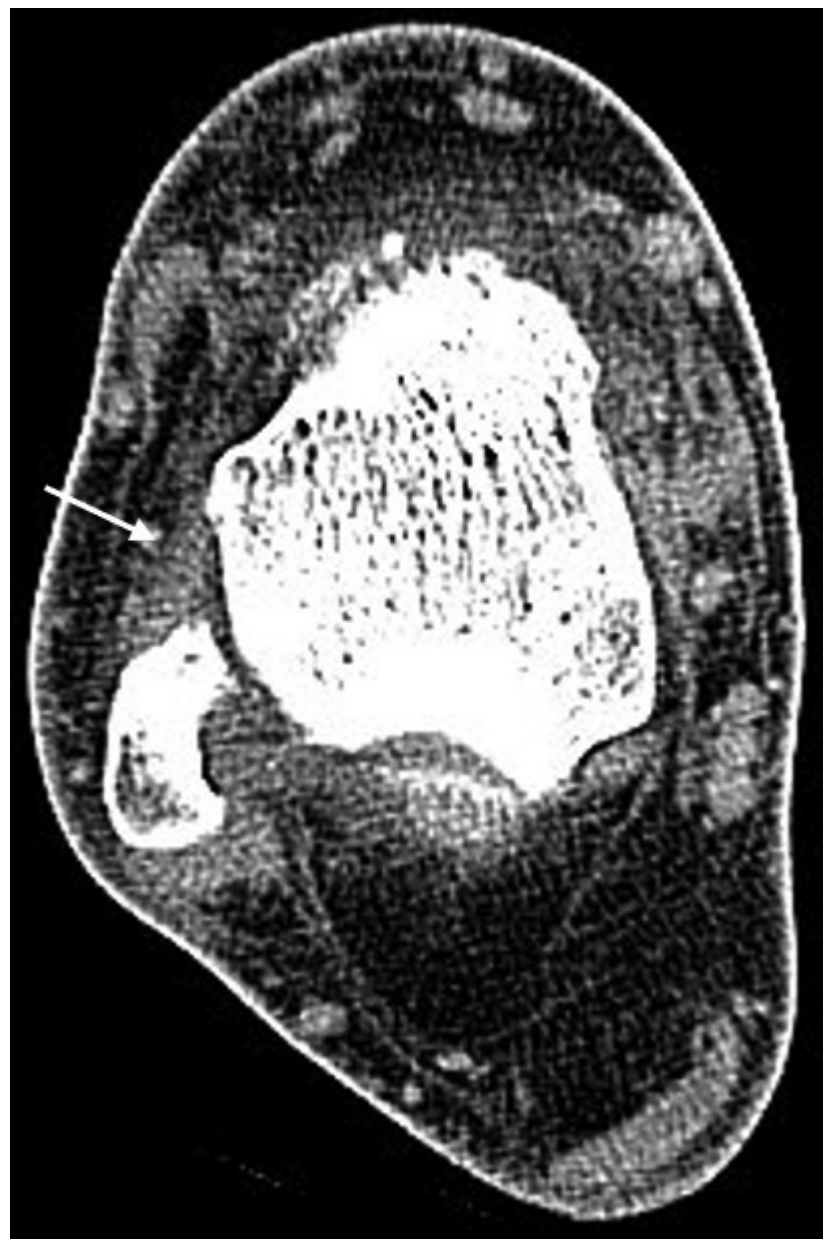

bility of determining the same grade in both tests was calculated.

\section{Statistical Analysis}

All the data were analyzed using SPSS version 20.0 software. The sensitivity, specificity, PPV, NPV, and accuracy of CT for ATFL tears were analyzed statistically. Sensitivity was calculated as the number of true positive examinations, divided by the number of true positive plus false negative examinations. Specificity was calculated as the number of true negative examinations, divided by the number of true negative plus false positive examinations. PPV was calculated as the number of true positive examinations, divided by the number of all true and false positive examinations. NPV was calculated as the

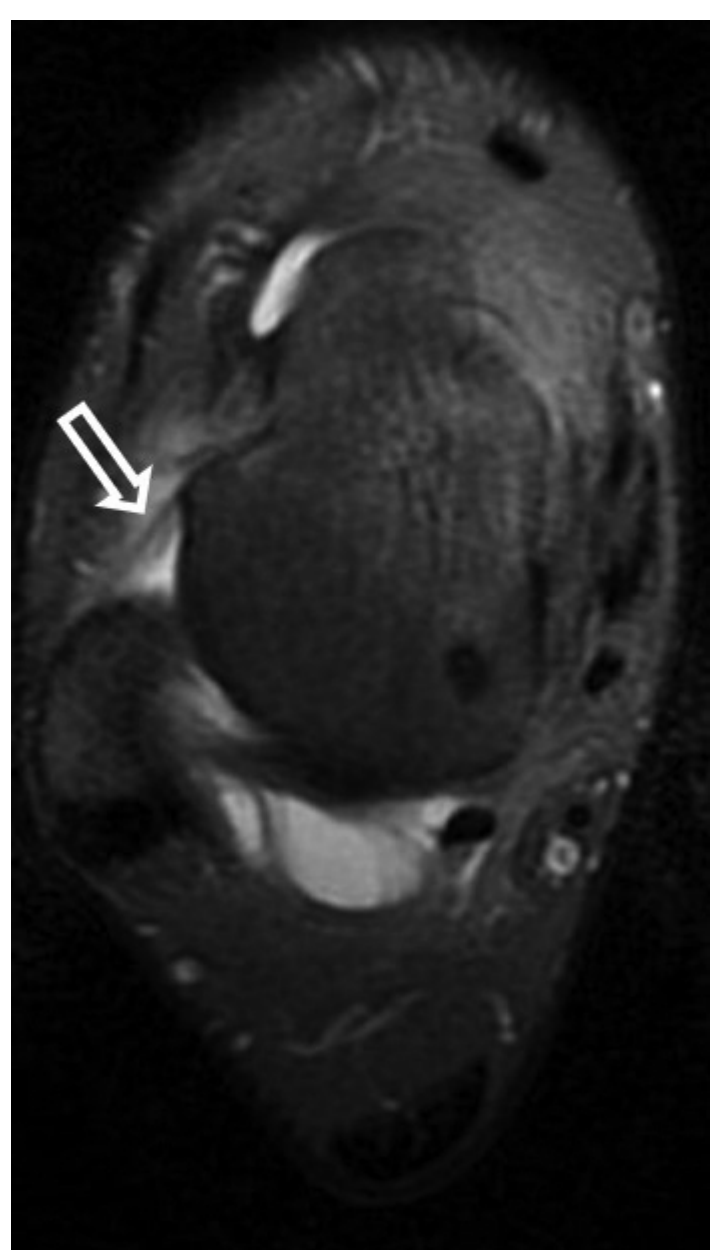

Figure 1. (a) Axial CT image shows the ATFL with a thicker appearance (arrow). (b) Axial proton density fat-suppressed image shows partial tear of the ATFL. Open arrow indicates remnant ATFL. It was accepted as a false negative result of CT. 
number of true negative examinations, divided by the number of all true and false negative examinations. Accuracy was calculated as the number of true positives plus true negative examinations, divided by the number of all cases.

\section{RESULTS}

A total of 60 patients were included in the study comprising 26 females and 34 males with a median age of 38.8 years (range, $14-72$ years).
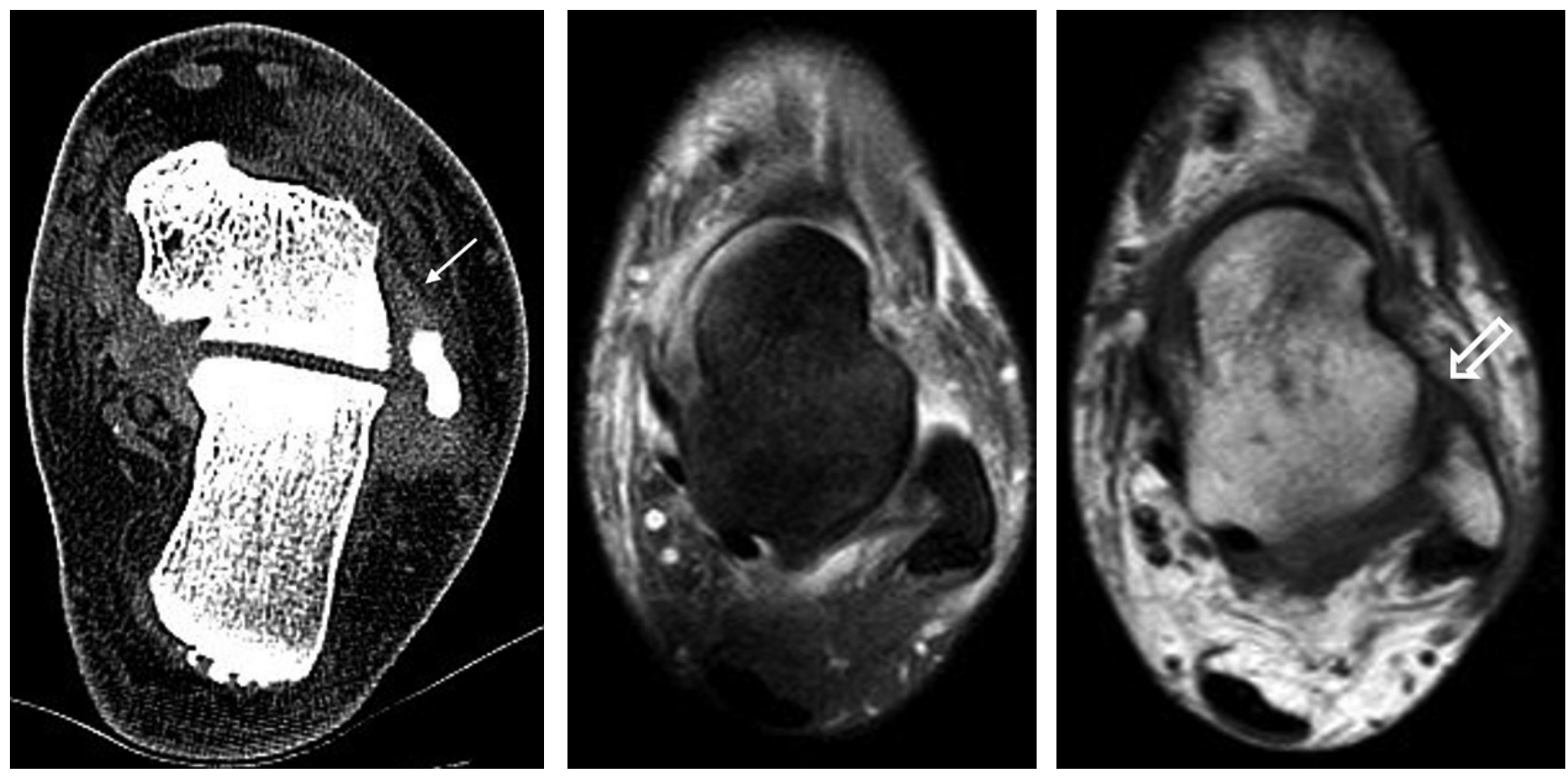

Figure 2. (a) Axial CT image shows the ATFL with a thicker appearance (arrow). (b) Axial proton density fat-suppressed and (c) T1-weighted images show partial tear of the ATFL. ATFL is seen thinner than normal (open arrow). It was accepted as a false negative result of CT.
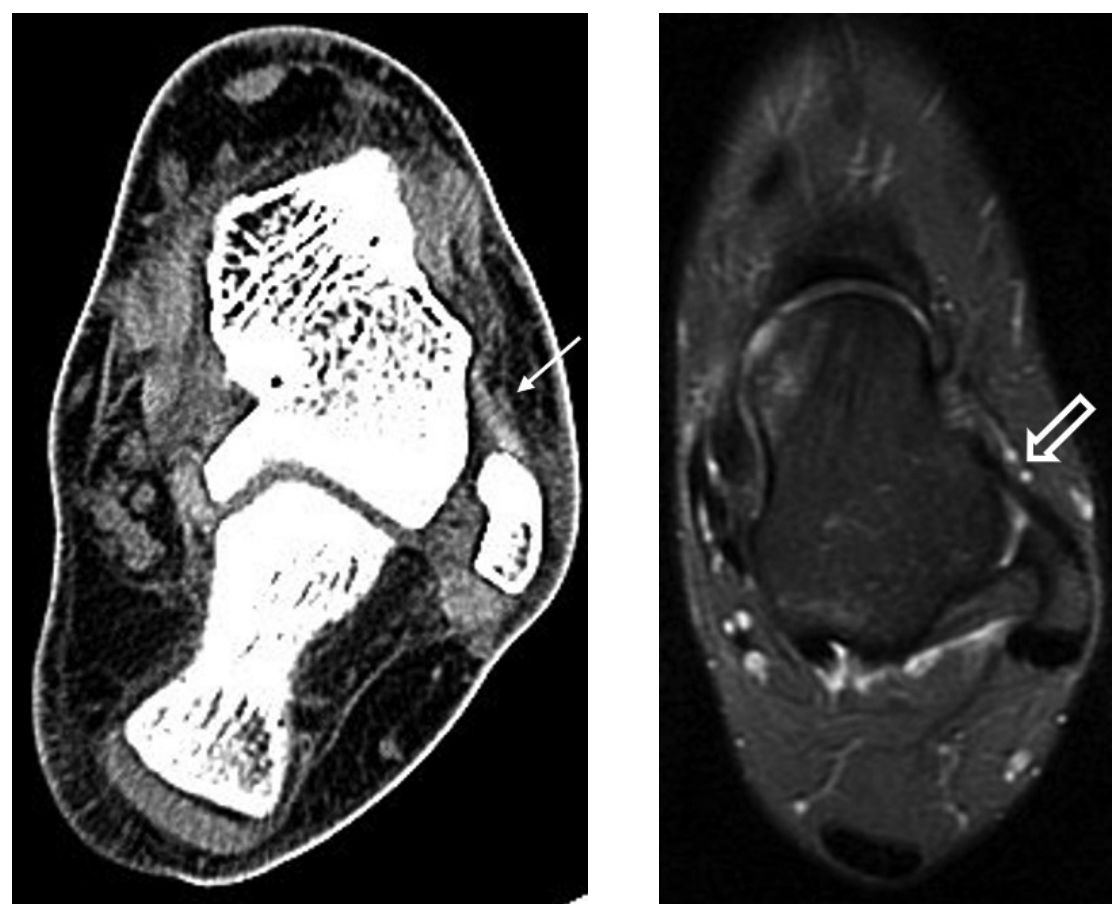

Figure 3. (a) Axial CT (arrow) and (b) axial proton density fat-suppressed (open arrow) images show the normal ATFL. It was accepted as a true negative result of CT. 

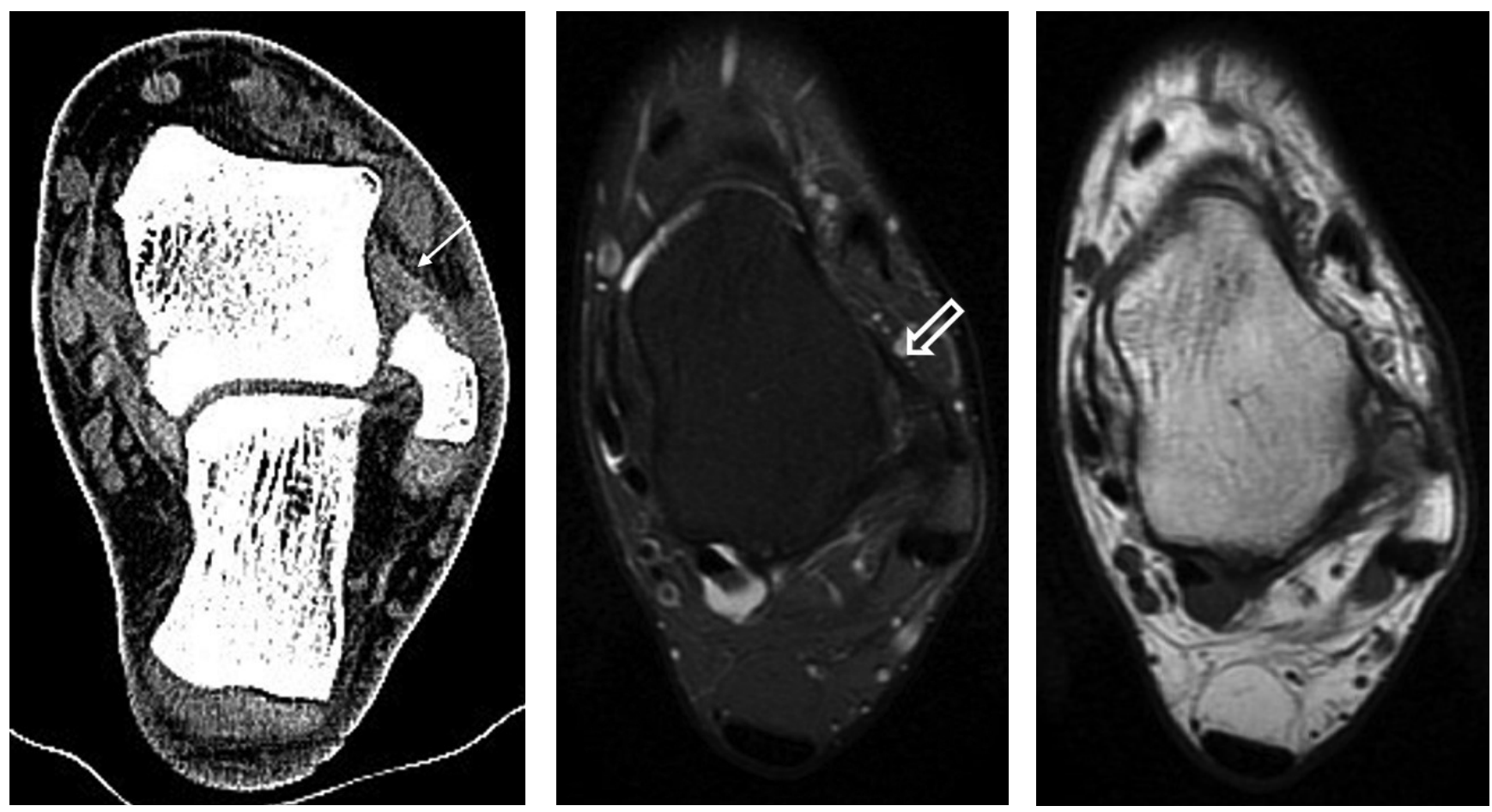

Figure 4. (a) Axial CT image shows the ATFL with a thicker appearance (arrow). (b) Axial proton density fat-suppressed and (c) axial T1-weighted (open arrows) images show the normal ATFL. Because it was not torn on both CT and MRI, it was accepted as a true negative result of CT.
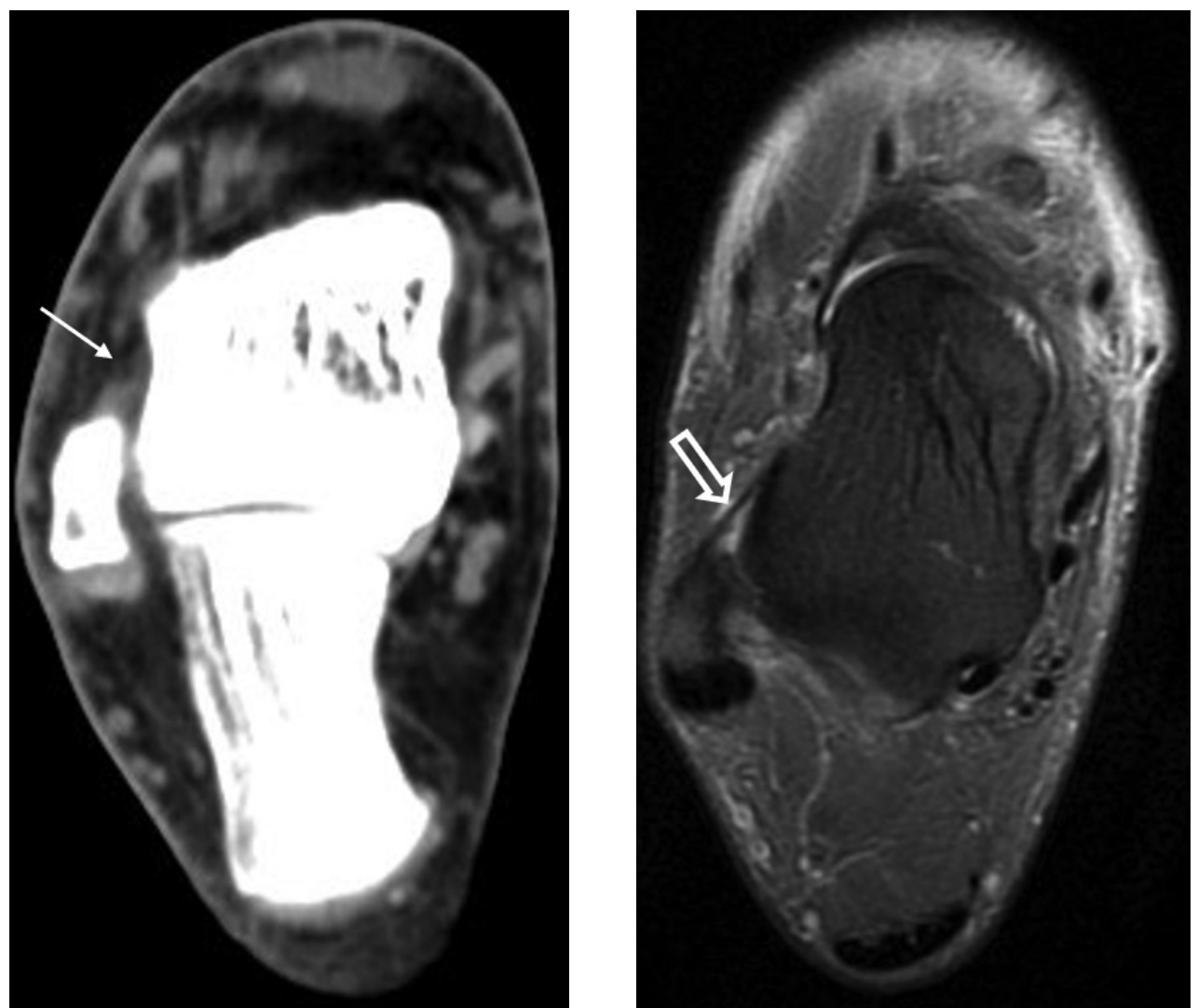

Figure 5. (a) Axial CT image shows the ATFL contour irregularity (arrow) and thinning in the talar side. It was accepted as a partial tear of ATFL. (b) Axial proton density fat-suppressed image shows the ATFL with a thinner appearance (partial tear). Open arrow indicates remnant ATFL. It was accepted as a true positive result of CT. 
When the $\mathrm{CT}$ results were evaluated accepting the $M R I$ results as the reference standard in the determination of ATFL tears, 2 false negative (Figure 1, 2), 55 true negative (Figure 3,4 ), and 5 true positive (Figure 5) results were determined. According to these results, CT was calculated to have $74.1 \%$ sensitivity, 100\% specificity, 100\% PPV, 96.4\% NPV and 96.7\% accuracy in the determination of ATFL injury (Table 1). In the 2 patients evaluated as false negative, the partially torn appearance on MRI was incorrectly evaluated as a thicker appearance than normal on CT. No complete tear was found in any of the 62 examinations of the 60 patients.

When the patients were separated according to grades; the CT and MRI results of 57 of the 62 cases demonstrated the same grade. Accordingly, in $91.9 \%$ of the cases both CT and MRI demonstrated the same grade (Table 1 ).

Table 1. The accuracy of $\mathrm{CT}$ in the determination of ATFL tears.

\begin{tabular}{|c|c|c|c|c|}
\hline \multirow[b]{2}{*}{ CT Findings } & \multicolumn{3}{|c|}{ MRI Findings } & \multirow{2}{*}{$\begin{array}{c}\begin{array}{c}\text { Statistical } \\
\text { Findings }\end{array} \\
\%\end{array}$} \\
\hline & Positive & Negative & Total & \\
\hline Positive & 5 & 0 & 5 & \\
\hline Negative & 2 & 55 & 57 & \\
\hline Total & 7 & 55 & 62 & \\
\hline Sensitivity & & & & $71.4 \%$ \\
\hline Specificity & & & & $100 \%$ \\
\hline PPV & & & & $100 \%$ \\
\hline NPV & & & & $96.4 \%$ \\
\hline Accuracy & & & & $96.7 \%$ \\
\hline Same classification on the & & & & $91.9 \%$ \\
\hline CT report as by MRI & & & & \\
\hline
\end{tabular}

MRI: Magnetic resonance imaging, CT: Computed tomography, ATFL: Anterior talofibular ligament, PPV: Positive predictive value, NPV: Negative predictive value.

\section{DISCUSSION}

The ATFL is the most frequently damaged ligament in ankle injuries. MRI is frequently used in the diagnosis of ATFL injuries because of its higher soft tissue resolution. Although there is currently increased availability of MRI devices, still CT is more frequently used in healthcare institutions. In addition, the imaging methods firstly performed on the patients presenting at the emergency department are usually direct radiographs and $\mathrm{CT}$. Generally, the presence of bone pathology is evaluated on CT, but ligament pathologies are excluded from the evaluation. Therefore, the hypothesis of the current study was that if ATFL injury could be demonstrated by ankle CT examination, there could be a change in the treatment planning or the patient could be referred for MRI. There are many studies in the literature showing that MRI has high accuracy in the determination of ATFL damage ${ }^{(3-5)}$. However, there are few studies that have evaluated the accuracy of 3-dimensional (3D) CT and CT arthrography in the evaluation of ATFL tears ${ }^{(6,7)}$. As CT arthrography is an interventional method it is not the first choice of imaging methods to be applied to trauma cases under emergency department conditions. To the best of our knowledge, there have been no studies in the literature that have examined the accuracy of CT in the determination of AFTL tears on standard CT slices, which are widely used in the evaluation of trauma cases in emergency departments. Nakasa T et al. (6) investigated the accuracy of 3D CT in the determination of ATFL injury in a series of 6 patients and compared the 3D CT results with MRI and surgical findings. In all the patients, normal ATFL could be determined as intact on $\mathrm{CT}$, but in patients with partial tears, residual intact fibers were detected more accurately on 3D CT than on MRI. The compatibility between radiological imaging methods and arthroscopy was investigated in chronic ATFL damage by Elkaim $\mathrm{M}$ et al. ${ }^{(7)}$, and the compatibility between $\mathrm{CT}$ arthrography and arthroscopy was found to be at a rate of $82 \%-88 \%$. In the same study, CT arthrography was found to have $89 \%$ sensitivity, $83 \%$ specificity, PPV 95\%, and NPV 66\% in the evaluation of ATFL injury. Despite the use of standard CT slices in the current study, the specificity (100\%), PPV (100\%) and NPV (96.4\%) of CT were extremely high. The finding of 2 false negative results in the current study caused a slight fall in the sensitivity to $71.4 \%$ which was still at an acceptable level. When the 2 patients with false negative results were examined, it was seen that while the ATFL damage was evaluated as a par- 
tial tear on MRI, the identified lesions were evaluated as having thicker appearance than normal, compatible with forced tear on CT. Cases with a partial tear, where a section of the ligament fibrils has been torn, can be effectively identified on MRI because of its higher soft tissue resolution. It has been thought that the ligament trace was seen as thickened soft tissue density because of the density changes that had formed from contusion and edema both in the torn ligament fibrils and in the surrounding soft tissue. Moreover, when the compatibility between CT and $\mathrm{MRI}$ was examined by separating the ATFL lesions into grades, the results of 57 of the 62 patients were determined to be the same both on $\mathrm{CT}$, and MRI. Of the 5 patients with incompatible $\mathrm{CT}$, and MRI results, 2 were patients evaluated as false negative on CT, and in 3, the ATFL was evaluated as normal (Grade 0) on MRI, whereas it was observed to be thicker than normal on CT (Grade 1). It was thought that the presence of increased edematous density in the surrounding soft tissue when the ligament was intact caused the misleading thicker than normal appearance of the ligament on CT.

The majority of AFTL tears are treated conservatively. However, there are studies in the literature showing that surgical treatment of AFTL tears provides better ankle stability and a more rapid return to work and sports ${ }^{(8)}$. Similarly in a meta-analysis by Pijnenburg et al. ${ }^{(9)}$, better results were shown with surgical treatment of AFTL. Therefore, if ATFL damage can be shown on CT images obtained with the suspicion of bone pathology in particular in a case of an ankle injury, surgical intervention can be performed before the development of lateral ankle instability, or the patient can be referred for MRI and a correct diagnosis can be made without overlooking the tear. Thus changes can be made both in the form of treatment to be applied and in the prediction of diagnosis. Indeed surgical intervention was not applied to AFTL injuries when there was no tear, patients were evaluated as normal even if there were findings compatible with forced tear on MRI and $\mathrm{CT}$, while partial or complete tears were evaluated in the tear group in the current study. Accordingly, the PPV of CT was calculated as $100 \%$ in the evaluation of ATFL tears. In other words, all the ATFL injuries determined as torn on CT were evaluated as torn on MRI. That the ligament can be evaluated as normal on CT examination is important in respect of avoiding unnecessary MRI examination. Therefore, evaluation of the ATFL during routine reporting of the ankle CT obtained following trauma can be considered important in the planning of the treatment.

A limitation of this study was that the $\mathrm{CT}$ results were compared with MRI results and not with the surgical results, which are the gold standard in the diagnosis. However, the effect of this limitation can be considered to have been minimal as both the CT and MR images in this study were evaluated by a single radiologist with 15 years of experience in the field of musculoskeletal radiology and MRI has high accuracy in the evaluation of AFTL tears. The retrospective nature of the study is one of the limitations. Because detailed clinical information was not available and clinical findings could not be compared with $\mathrm{CT}$ and MRI results. Another limitation of the study was that there were no cases of complete tears in the patient series. This study can be considered as a preliminary study in this area for further studies with larger scale series should be conducted. Another limitation of the study was that the images were evaluated by a single radiologist. In a further study with larger series, images can be evaluated by at least 2 different radiologists so that intra and interobserver reliability of CT in the determination of ATFL tears can be determined.

In conclusion, the results of this study showed that CT has high accuracy in the differentiation of intact ATFL from torn ATFL, and with the support of further extensive studies, has the potential for use in this area. Especially under emergency department conditions, the determination of whether the ATFL is 
intact or torn on $\mathrm{CT}$, which is usually applied for the evaluation of bone pathologies, can refer the patient for MRI, change the treatment modality and the prognosis.

Ethics Committee Approval: Izmir Katip Celebi University Non-Interventional Clinical Studies Institutional Review Board was approved (27.03.2019/124).

Conflict of Interest: The authors declare that there is no conflict of interests regarding the publication of this paper.

Funding: No financial support was received.

Etik Kurul Onayı: İzmir Katip Çelebi Üniversitesi Girişimsel Olmayan Klinik Araştırmalar Etik Kurul onayı alınmıştır (27.03.2019/124).

Çıkar Çatışması: Yazarlar, bu makalenin yayınlanmasıyla ilgili olarak herhangi bir çıkar çatışması olmadığını beyan etmektedir.

Finansal Destek: Finansal destek alınmamıştır.

\section{REFERENCES}

1. Fallat L, Grimm DJ, Saracco JA. Sprained ankle syndrome: prevalence and analysis of 639 acute injuries. J Foot Ankle
Surg. 1998;37:280-5. [CrossRef]

2. Corte-Real MN, Moreira RMM. Arthroscopic Repair of Chronic Lateral Ankle Instability. Foot Ankle Int. 2009;5:213-7. [CrossRef]

3. Joshy S, Abdulkadir U, Chaganti S, Sullivan B, Hariharan K. Accuracy of MRI scan in the diagnosis of ligamentous and chondral pathology in the ankle. Foot Ankle Surg. 2010;16:7880. [CrossRef]

4. Oae K, Takao M, Uchio Y, Ochi M. Evaluation of anterior talofibular ligament injury with stress radiography, ultrasonography and MR imaging. Skeletal Radiol. 2010;39:41-7. [CrossRef]

5. Morvan A, Klouche S, Thes A, Hardy P, Bauer T. Reliability and validity of preoperative MRI for surgical decision making in chronic lateral ankle instability. Eur J Orthop Surg Traumatol. 2018;28:713-9. [CrossRef]

6. Nakasa T, Fukuhara K, Adachi N, Ochi M. Evaluation of anterior talofibular ligament lesion using 3-dimensional computed tomography. J Comput Assist Tomogr. 2006;30:543-7. [CrossRef]

7. Elkaïm $M$, Thès $A$, Lopes $R$, et al. Agreement between arthroscopic and imaging study findings in chronic anterior talo-fibular ligament injuries. Orthop Traumatol Surg Res. 2018;104:213-8. [CrossRef]

8. Kerkhoffs GM, Handoll HH, de Bie R, Rowe BH, Struijs PA. Surgical versus conservative treatment for acute injuries of the lateral ligament complex of the ankle in adults. Cochrane Database Syst Rev. 2007;18:CD000380. [CrossRef]

9. Pijnenburg ACM, van Dijk CN, Bossuyt PM, Marti RK. Treatment of ruptures of the lateral ankle ligaments: a metaanalysis. J Bone Joint Surg. 2000;82-A:761-73. [CrossRef] 